\title{
Praktikalitas E-modul Redoks dan Sel Elektrokimia Berbasis GDL untuk Kelas XII SMA
}

\section{Practicality of Redox and Electrochemical Cells E-Module Based on GDL for Class XII SMA}

\author{
A Mareza ${ }^{1}$ and Yerimadesi ${ }^{1 *}$ \\ 1 Pendidikan Kimia, Universitas Negeri Padang, \\ Jl. Prof. Dr. Hamka, Air Tawar Barat, Padang Utara, Sumatera Barat, Indonesia 25171 \\ *yeri@fmipa.unp.ac.id
}

\section{ARTICLE INFO Received on: 08 February 2021 \\ Revised till: \\ 31 July 2021 \\ Accepted on: 31 July 2021 \\ Publisher version published on: \\ 08 September 2021}

\begin{abstract}
Teaching materials are said to be practical if the practitioners or the experts state that the developed teaching materials can be applied in the research. The purpose of this research is to reveal the practicality of redox e-modules and GDL-based electrochemical cells for XII grade of high school students. This research is a continuation of educational design research with the Plomp development model at the prototyping stage, this research was conducted at SMAN 1 Lintau Buo Utara. The data were analyzed with the Aiken's V formula. The results of one-to-one evaluation showed that the e-module uses clear fonts, covers and attractive designs, the language used is easy to understand, the presentation of coherent material, videos and animations can help students to understand the material. The results of the analysis on the average Aiken's $V$ formula obtained a $V$ value of 0.88 at the small group stage and 0.86 at the high category field test stage. This data is evidenced by the ability of students to answer questions on the e-module by $90.5 \%$ with a very high category. Based on the data analysis, it is concluded that the e-module redox and electrochemical cells based on GDL are practically used in the learning process with a high practicality category.
\end{abstract}

\section{KEYWORDS}

E-Modules, Guided Discovery Learning, Plomp Models, Practicality, Redox and Electrochemical Cells

\begin{abstract}
ABSTRAK
Bahan ajar dikatakan praktis jika praktisi atau ahli menyatakan bahwa bahan ajar yang dikembangkan dapat diterapkan di lapangan. Penelitian ini bertujuan untuk mengungkapkan tingkat praktikalitas e-modul redoks dan sel elektrokimia berbasis GDL untuk kelas XII SMA. Penelitian ini merupakan lanjutan dari penelitian educational design research dengan model pengembangan Plomp pada tahap prototyping stage, yaitu pembentukan prototipe III sampai pada assessment phase. Penelitian ini dilakukan di SMAN 1 Lintau Buo Utara. Data dianalisis dengan formula Aiken's V. Hasil one to one evaluation menunjukkan bahwa e-modul menggunakan huruf yang jelas, cover dan desain yang menarik, bahasa yang digunakan mudah dimengerti, penyajian materi runtut, video dan animasi dapat membantu peserta didik dalam memahami materi. Hasil analisis data rata-rata formula Aiken's V diperoleh nilai V sebesar 0,88 pada tahap small group dan 0,86 pada tahap field test dengan kategori tinggi. Data ini dibuktikan dengan kemampuan peserta didik menjawab pertanyaan pada e-modul sebesar 90,5\% dengan kategori sangat tinggi. Berdasarkan analisis data disimpulkan bahwa e-modul redoks dan sel elektrokimia berbasis GDL praktis digunakan dalam proses pembelajaran dengan kategori kepraktisan tinggi.
\end{abstract}

KATA KUNCI

E-Modul, Guided Discovery Learning, Model Plomp, Praktikalitas, Redoks dan Sel Elektrokimia 


\section{PENDAHULUAN}

Pandemi Global Covid-19 yang dipandang berefek negatif ternyata di sisi lain masih menyimpan dampak positif bagi dunia pendidikan ${ }^{[1]}$. Proses belajar mengajar yang dulunya masih didominasi oleh model konvensional, untuk saat sekarang harus menggunakan teknologi digital seperti tuntutan era 4.0, sehingga seluruh pihak harus mampu beradaptasi dan terampil dengan penggunaan teknologi informasi dan komunikasi seperti yang dibutuhkan pada abad ke 21 sesuai dengan tuntutan kurikulum 2013, yang menuntut adanya peningkatan keseimbangan pengetahuan, sikap dan keterampilan,yang menekankan pada pendekatan saintifik ${ }^{[2]}$.

Pendekatan saintifik dapat memicu keaktifan peserta didik dalam proses pembelajaran. Dengan meningkatnya keaktifan peserta didik, maka guru akan lebih mudah dalam mengajarkan materi $^{[3]}$. Pendekatan ilmiah dapat diterapkan dengan model pembelajaran, model yang bisa dikembangkan untuk mempermudah peserta didik menemukan konsep sendiri pada pembelajaran yaitu model guided discovery learning (GDL) ${ }^{[4]}$.

GDL merupakan model pembelajaran yang dapat meningkatkan motivasi dan keaktifan peserta didik bisa ditingkatkan ${ }^{[5]}$, dengan model GDL maka keterampilan pemecahan masalah oleh peserta didik dapat ditingkatkan ${ }^{[6]}$. Tujuan dari model GDL adalah untuk melatih peserta didik dalam menemukan konsep pembelajaran secara mandiri ${ }^{[7]}$. Pada model pembelajaran ini, peserta didik dibimbing untuk melakukan kegiatan secara mandiri dengan bimbingan guru, sehingga menemukan konsep pembelajaran ${ }^{[8]}$. Dalam model pembelajaran ini, guru harus membimbing peserta didik menuju penemuan ${ }^{[9]}$ peserta didik tidak lagi hanya menerima materi, namun peserta didik ikut terlibat secara aktif untuk menemukan konsep materi yang dipelajari dalam proses pembelajaran.

Model GDL dapat diimplementasikan dalam proses pembelajaran dan diintegrasikan dalam sebuah modul elektronik (e-modul). E-modul yang interaktif merupakan pemanfaatan teknologi informasi dalam bidang pendidikan yang biasa dinamakan dengan e-modul berbasis GDL. Sesuai kurikulum 2013, redoks dan sel elektrokimia dipelajari di kelas XII SMA. Pada materi ini terdapat dimensi pengetahuan faktual, metakognitif, konseptual dan prosedural. Peserta didik kesulitan dalam memahami dan mengaplikasikan konsep reaksi yang terjadi ${ }^{[10-11]}$.

Bahan ajar merupakan suatu sumber yang memudahkan guru dalam proses pembelajaran ${ }^{[12]}$. Bahan ajar sangat berguna sebagai pedoman dalam aktivitas pembelajaran sesuai dengan tuntutan perkembangan kurikulum ${ }^{[13]}$. Dengan adanya bahan ajar yang digunakan sebagai pedoman, guru dan peserta didik akan lebih mudah dalam melakukan proses pembelajaran.
Beberapa penelitian tentang e-modul telah menunjukkan hasil yang valid dan efektif untuk digunakan, diantaranya materi kimia unsur, larutan elektrolit dan non elektrolit ${ }^{[14]}$. E-modul redoks dan sel elektrokimia berbasis GDL telah menunjukkan hasil yang valid untuk digunakan, namun tingkat kepraktisannya belum diujikan.

Praktikalitas merupakan tingkat keterpakaian suatu bahan ajar, bahan ajar dinilai praktis di saat materi yang disajikan tidak sulit dipahami oleh pengguna, memiliki petunjuk penggunaan yangjelas sertamudahdalam proses pemeriksaannya. Bahan ajar dikatakan praktis jika praktisi atau ahli menyatakan bahwa bahan ajar yang dikembangkan dapat diterapkan di lapangan. Kepraktisan bahan ajar yang dikembangkan dapat dilihat dari tingkat kemudahan penggunaan dan keterbantuan dalam penggunaannya, dan juga dapat dilihat dari beberapa aspek, yaitu aspek mudah dimengerti oleh peserta didik, produk membuat peserta didik lebih paham, kemenarikan produk, evaluasi, dan model pendekatan yang digunakan.

Aspek praktikalitas yang diukur adalah aspek kemudahan penggunaan dan penyajian. Aspek kemudahan penggunaan meliputi kemudahan memahami materi dan bahasa yang digunakan dalam e-modul. Sedangkan penyajian fokus dalam tampilan e-modul. Bahan ajar yang menunjukkan hasil belum praktis akan diperbaiki kembali dan hasil perbaikan harus divalidasi.

Berdasarkan observasi yang telah dilakukan kepada guru dan siswa kelas XII IPA di SMA 1 Lintau Buo, diperoleh informasi bahwa a) sebagian besar siswa kesulitan dalam memahami materi redoks dan sel elektrokimia; b) guru menggunakan media pembelajaran berupa modul, power point, buku paket dan makalah ilmiah pada materi redoks dan sel elektrokimia; c) media yang digunakan masih belum sepenuhnya membuat siswa belajar secara aktif; d) 100\% siswa dan guru belum pernah menggunakan e-modul dalam proses pembelajaran; e) siswa dan guru tertarik jika dalam pembelajaran redoks dan sel elektrokimia digunakan media pembelajaran berupa e-modul berbasis GDL. Oleh karena itu dilakukan penelitian lanjutan untuk mengungkapkan praktikalitas dari e-modul redoks dan sel elektrokimia berbasis GDL untuk kelas XII SMA sehingga e-modul yang telah dikembangkan dapat digunakan dalam proses pembelajaran.

\section{METODE}

Penelitian ini merupakan lanjutan dari penelitian educational design research, yang telah dilakukan sampai pada tahap prototyping stage bagian expert review. Model yang digunakan adalah model pengembangan Plomp yang dilakukan pada tahap prototyping stage untuk one to one evaluation sampai pada tahap assessment phase ${ }^{[15]}$. Subjek dalam penelitian ini adalah 3 orang guru kimia, dan 39 orang peserta didik kelas XII SMAN 1 Lintau Buo. 
Tahap uji pertama yaitu one to one evaluation untuk pembentukan prototipe III. Pada tahap ini, diberikan e-modul kepada peserta didik dengan kemampuan berbeda (tinggi, sedang, dan rendah), dijelaskan kepada peserta didik tentang komponen e-modul tersebut, kemudian peserta didik diminta menjawab pertanyaan yang terdapat pada e-modul dan memberikan penilaian terhadap e-modul melalui lembar wawancara yang diberikan.

Selanjutnya small group evaluation (uji coba kelompok kecil) yang dilakukan dengan cara memberikan e-modul kepada enam orang peserta didik yang mempunyai kemampuan berbeda, dijelaskan kepada peserta didik tentang komponen e-modul, kemudian peserta didik menjawab pertanyaan yang terdapat pada e-modul dan memberikan penilaian terhadap e-modul melalui angket praktikalitas yang diberikan.

Tahap selanjutnya yaitu assessment phase (tahap penilaian) dengan melakukan uji lapangan (field test) yang bertujuan untuk mengevaluasi dan mengungkapkan tingkat praktikalitas e-modul. Pengujian ini dilakukan kepada 3 orang guru kimia dan 36 orang peserta didik. Diberikan e-modul kepada guru dan peserta didik, dijelaskan tentang komponen e-modul, dan peserta didik menjawab pertanyaan yang terdapat pada e-modul, selanjutnya guru dan peserta didik memberikan penilaian terhadap e-modul melalui angket praktikalitas yang diberikan. Data yang diperoleh dianalisis menggunakan formula Aiken's $\mathrm{V}^{[16]}$.

\section{HASIL DAN DISKUSI}

E-modul merupakan bahan ajar yang disajikan dalam bentuk modul elektronik yang dapat digunakan melalui komputer dengan memakai software yang diperlukan ${ }^{[17]}$. E-modul merupakan sebuah bentuk penyajian bahan belajar mandiri yang disusun secara sistematis ke dalam unit pembelajaran tertentu, yang disajikan dalam format elektronik, dimana setiap kegiatan pembelajaran di dalamnya dihubungkan dengan tautan (link) sebagai navigasi yang membuat sistem menjadi interaktif dengan program, dilengkapi dengan penyajian video tutorial, animasi dan audio untuk memperkaya pengalaman belajar ${ }^{[17]}$.

Model pembelajaran yang mampu membimbing peserta didik belajar secara mandiri, mempunyai pengetahuan dan dapat menemukan konsep secara mandiri salah satunya model guided discovery learning. Model pembelajaran ini berdasarkan pada penemuan konsep yang ditemukan sendiri oleh peserta didik secara mandiri, guru berperan membimbing peserta didik agar peserta didik tidak kesulitan dan tidak kebingungan saat proses pembelajaran.

E-modul berbasis GDL ini menyajikan materi pada tiap kegiatan yang terdiri dari tahap pendahuluan, tahap pembentukan prototipe, dan tahap penilaian. Dari tiga tahapan tersebut, tahap pendahuluan, pembentukan prototipe I, dan II, telah dilakukan sebelumnya.
Kepraktisan bahan ajar dapat dilihat dari bahan ajar yang dikembangkan dapat diterapkan dengan baik dalam proses pembelajaran serta membantu memberikan manfaat dan kemudahan dalam penggunaannya di lapangan. Praktikalitas bahan ajar berkaitan dengan tingkat kemudahan penggunaan dan waktu pelaksanaan pembelajaran yang dilihat dari pertimbangan materi yang mudah dipahami serta mudah diakses oleh guru dan peserta didik ${ }^{[18]}$.

\subsection{Prototyping Stage.}

\subsubsection{Pembentukan Prototype III.}

\subsubsection{One to One Evaluation.}

One to one evaluation dilakukan terhadap tiga orang peserta didik kelas XII SMAN 1 Lintau Buo yang telah mempelajari materi redoks danselelektrokimia.Darihasilwawancara diperoleh gambaran bahwa, huruf yang digunakan pada e-modul jelas, hal ini sesuai dengan karakteristik dari e-modul yaitu jelas dan mudah dimengerti ${ }^{[17]}$. Cover dan desain warna tampilan e-modul bagus sehingga menarik minat peserta didik untuk membacanya. Adanya e-modul yang didesain dengan menarik akan meningkatkan motivasi peserta didik dalam membaca materi pembelajaran $^{[19]}$ dan bahasa yang digunakan mudah untuk dimengerti.

Penyajian materi pada e-modul tersusun secara runtut, sehingga menuntun peserta didik untuk menemukan pengetahuan baru, gambar, tabel dan video pembelajaran yang terdapat pada e-modul dapat membantu peserta didik dalam memahami materi, karena peserta didik akan lebih tertarik untuk mempelajari materi yang diberikan melalui fitur yang diberikan ${ }^{[20]}$.

\subsubsection{Prototype IV.}

Hasil uji praktikalitas terhadap beberapa aspek dari e-modul melalui uji coba kelompok kecil (small group) dapat dilihat pada Tabel 1.

Tabel 1. Hasil Praktikalitas E-Modul pada uji Small Group.

\begin{tabular}{c|c|c}
$\begin{array}{c}\text { Aspek yang } \\
\text { dinilai }\end{array}$ & Aiken's V & $\begin{array}{c}\text { Kategori } \\
\text { Kepraktisan }\end{array}$ \\
\hline $\begin{array}{c}\text { Kemudahan } \\
\text { Penggunaan }\end{array}$ & 0,88 & $\begin{array}{c}\text { Praktikalitas } \\
\text { tinggi }\end{array}$ \\
\hline $\begin{array}{c}\text { Efisiensi waktu } \\
\text { pembelajaran }\end{array}$ & 0,85 & $\begin{array}{c}\text { Praktikalitas } \\
\text { tinggi }\end{array}$ \\
\hline Pemanfaatan & 0,88 & $\begin{array}{c}\text { Praktikalitas } \\
\text { tinggi }\end{array}$ \\
\hline $\begin{array}{c}\text { Rata-rata } \\
\text { kepraktisan }\end{array}$ & $\mathbf{0 , 8 8}$ & $\begin{array}{c}\text { Praktikalitas } \\
\text { tinggi }\end{array}$
\end{tabular}

Dari hasil analisis data praktikalitas diperoleh rata-rata nilai Aiken's V dari seluruh komponen praktikalitas sebesar 0,88 dengan kategori kepraktisan yang tinggi. Hal ini membuktikan bahwa e-modul redoks dan sel elektrokimia berbasis GDL 
Tabel 2. Hasil Analisis Jawaban Peserta didik pada Tahap Small Group.

\begin{tabular}{|c|c|c|c|c|c|c|}
\hline \multirow{2}{*}{ Tahap } & \multicolumn{5}{|c|}{ \% kemampuan peserta didik dalam menjawab } & \multirow{2}{*}{ Rata-rata } \\
\hline & LK1 & LK 2 & LK 3 & LK 4 & LK5 & \\
\hline $\mathrm{PP}$ & 100 & 92 & 100 & 94 & 92 & 95 \\
\hline DP & 94,4 & 75 & 85 & 74 & 100 & 84 \\
\hline $\mathrm{V}$ & 33,3 & 100 & 90 & 92 & 94 & 89 \\
\hline $\mathrm{C}$ & 87 & 90 & 100 & 94 & 97 & 94 \\
\hline Rata-rata LK & 90 & 85 & 92 & 82 & 95 & 90,5 \\
\hline Kategori & $\begin{array}{l}\text { Sangat } \\
\text { Tinggi }\end{array}$ & Tinggi & $\begin{array}{l}\text { Sangat } \\
\text { Tinggi }\end{array}$ & Tinggi & $\begin{array}{l}\text { Sangat } \\
\text { Tinggi }\end{array}$ & Sangat Tinggi \\
\hline
\end{tabular}

praktis digunakan oleh peserta didik dalam proses pembelajaran baik dari segi aspek kemudahan penggunaan, efisiensi waktu pembelajaran dan pemanfaatan. Hal ini juga didukung oleh persentase kemampuan peserta didik dalam menjawab pertanyaan yang terdapat pada e-modul yang dapat dilihat pada Tabel 2.

Dari hasil analisis data terhadap kemampuan peserta didik dalam menjawab e-modul, diperoleh rata-rata persentase kemampuan peserta didik dalam menjawab e-modul sesuai dengan langkah GDL sebesar 90,5\% dengan kategori sangat tinggi. Meskipun prototipe III telah menunjukkan kepraktisan yang tinggi, namun masih diperlukan revisi dari segi kemudahan penggunaan e-modul agar e-modul dapat digunakan secara praktis, karena sebelumnya e-modul masih bergantung kepada aturan-aturan penggunaan yang terikat pada aplikasi tertentu. Revisi yang dilakukan akan menghasilkan prototipe IV, dan hasil revisi diujikan pada tahap penilaian.

\subsection{Assessment Phase}

Pada tahap penilaian diperoleh nilai praktikalitas e-modul dari guru dan peserta didik. Hasil penilaian praktikalitas pada field test terhadap e-modul pada masing-masing aspek dapat dilihat pada Tabel 3.

Dari hasil analisis data diperoleh nilai Aiken's V kepraktisan e-modul dari aspek kemudahan penggunaan sebesar 0,88 dari guru dan 0,85 dari peserta didik dengan kategori kepraktisan tinggi. Hal ini menunjukkan bahwa e-modul telah memiliki petunjuk penggunaan yang jelas dan mudah dipahami.

Dari aspek efisiensi waktu pembelajaran, diperoleh nilai rata-rata Aiken's $\mathrm{V}$ sebesar 0,83 dari guru dan 0,85 dari peserta didik dengan kategori kepraktisan tinggi. Hal ini menunjukkan bahwa e-modul mampu membuat peserta didik belajar sesuai kemampuan dan kecepatannya sendiri. Pembelajaran dengan menggunakan e-modul dapat membuat waktu pembelajaran menjadi lebih efisien dan peserta didik dapat belajar dengan kecepatannya masing-masing.
Tabel 3. Hasil Uji Praktikalitas E-Modul pada Uji Field Test.

\begin{tabular}{c|c|c|c}
$\begin{array}{c}\text { Aspek yang } \\
\text { dinilai }\end{array}$ & Guru & $\begin{array}{c}\text { Peserta } \\
\text { didik }\end{array}$ & $\begin{array}{c}\text { Kategori } \\
\text { Kepraktisan }\end{array}$ \\
\hline $\begin{array}{c}\text { Kemudahan } \\
\text { Penggunaan }\end{array}$ & 0,88 & 0,85 & $\begin{array}{c}\text { Praktikalitas } \\
\text { tinggi }\end{array}$ \\
\hline $\begin{array}{c}\text { Efisiensi } \\
\text { waktu pem- } \\
\text { belajaran }\end{array}$ & 0,83 & 0,85 & $\begin{array}{c}\text { Praktikalitas } \\
\text { tinggi }\end{array}$ \\
\hline $\begin{array}{c}\text { Pemanfaatan } \\
\text { Formula }\end{array}$ & 0,86 & 0,88 & $\begin{array}{c}\text { Praktikalitas } \\
\text { tinggi }\end{array}$ \\
\hline Aiken's V & 0,86 & 0,86 & $\begin{array}{c}\text { Praktikalitas } \\
\text { tinggi }\end{array}$ \\
\hline $\begin{array}{c}\text { Rata-rata } \\
\text { Kepraktisan }\end{array}$ & $\mathbf{0 , 8 6}$ & $\begin{array}{c}\text { Praktikalitas } \\
\text { Tinggi }\end{array}$
\end{tabular}

Model pembelajaran guided discovery learning dapat menghemat waktu karena tahapannya terperinci dan mudah dipahami oleh siswa. Dari aspek pemanfaatan e-modul memiliki nilai Aiken's V sebesar 0,86 dari guru dan 0,88 dari peserta didik dengan kategori kepraktisan tinggi. E-modul redoks dan sel elektrokimia berbasis guided discovery learning dapat membantu peserta didik belajar mandiri dan menemukan konsep secara mandiri melalui pertanyaan-pertanyaan yang disajikan dalam e-modul, sehingga dapat memotivasi dan meningkatkan semangat peserta didik dalam belajar.

Dari hasil analisis data diperoleh kepraktisan e-modul dengan nilai rata-rata Aiken's $\mathrm{V}$ sebesar 0,86 dengan kategori kepraktisan tinggi. Hal ini juga didukung dengan persentase kemampuan peserta didik dalam menjawab e-modul yang dapat dilihat pada Tabel 4 .

Rata-rata persentase kemampuan peserta didik dalam menjawab e-modul sesuai dengan tahapan GDL sebesar 90,5\% dengan kategori sangat tinggi. Namun, pada LK 1 nilai peserta didik pada tahap 
Tabel 4. Hasil Analisis Jawaban Peserta didik pada Tahap Small Group.

\begin{tabular}{|c|c|c|c|c|c|c|}
\hline \multirow{2}{*}{ Tahap } & \multicolumn{5}{|c|}{ \% kemampuan peserta didik dalam menjawab } & \multirow{2}{*}{ Rata-rata } \\
\hline & LK1 & LK 2 & LK 3 & LK 4 & LK5 & \\
\hline $\mathrm{PP}$ & 100 & 97 & 98 & 94 & 98 & 95 \\
\hline DP & 84 & 74 & 83 & 72 & 92 & 84 \\
\hline $\mathrm{V}$ & 65 & 96 & 92 & 91 & 94 & 89 \\
\hline $\mathrm{C}$ & 84 & 93 & 94 & 85 & 93 & 94 \\
\hline Rata-rata LK & 84 & 90 & 92 & 80 & 94 & 90,5 \\
\hline Kategori & Tinggi & Tinggi & $\begin{array}{l}\text { Sangat } \\
\text { Tinggi }\end{array}$ & Tinggi & $\begin{array}{l}\text { Sangat } \\
\text { Tinggi }\end{array}$ & Sangat Tinggi \\
\hline
\end{tabular}

verification adalah rendah, hal ini membuktikan bahwa materi redoks dan sel elektrokimia merupakan materi yang sulit ${ }^{[10]}$, peserta didik membutuhkan pemahaman yang lebih mendalam untuk mampu memahami materi tersebut. Hal ini dapat dilihat dari analisis jawaban peserta didik berdasarkan indikator pencapaian kompetensi (IPK) pada materi ini, yang dapat dilihat pada Tabel 5 .

Dari hasil analisis data yang dilihat dari tingkat ketercapaian indikator pencapaian kompetensi (IPK) yang terdapat pada e-modul, diperoleh gambaran bahwa LK 1 dan LK2 tidak dapat dipahami oleh peserta didik hanya dalam satu kali pertemuan saja, karena pada IPK tersebut peserta didik membutuhkan tingkat pemahaman yang tinggi untuk menjawab pertanyaan-pertanyaan yang terdapat pada e-modul. Hal tersebut dibuktikan dengan rendahnya skor yang diperoleh oleh peserta didik pada tahap data processing, verification dan kemampuan peserta didik dalam menjawab soal pada LKPD yang terdapat pada e-modul.

Setelah uji coba field test terhadap prototipe IV, secara umum prototipe yang dihasilkan sudah baik digunakan dalam proses pembelajaran, sehingga dihasilkan prototipe final berupa e-modul redoks dan sel elektrokimia berbasis GDL untuk kelas XII SMA yang telah praktis.

\section{SIMPULAN}

Dari hasil dan analisis data penelitian yang diperoleh disimpulkan bahwa e-modul redoks dan sel elektrokimia berbasis GDL untuk peserta didik kelas XII SMA praktis digunakan dengan

Tabel 5. Analisis Jawaban Peserta didik Berdasarkan Indikator Pencapaian Kompetensi (IPK).

\begin{tabular}{|c|c|c|c|c|c|c|c|c|c|c|}
\hline \multirow{2}{*}{ Tahap } & \multicolumn{2}{|c|}{ LK1 } & \multicolumn{2}{|c|}{ LK 2} & \multicolumn{2}{|c|}{ LK 3} & \multicolumn{2}{|c|}{ LK 4} & \multicolumn{2}{|c|}{ LK 5} \\
\hline & SM & SP & SM & SP & SM & SP & SM & SP & SM & SP \\
\hline PP & 12 & 12 & 12 & 11 & 12 & 12 & 18 & 17 & 12 & 11 \\
\hline DP & 125 & 118 & 60 & 45 & 60 & 51 & 114 & 84 & 18 & 18 \\
\hline V & 12 & 5 & 24 & 24 & 42 & 38 & 24 & 22 & 48 & 45 \\
\hline C & 30 & 26 & 30 & 27 & 54 & 54 & 36 & 34 & 30 & 29 \\
\hline Jumlah & 179 & 161 & 126 & 107 & 168 & 155 & 192 & 157 & 108 & 103 \\
\hline Nilai & \multicolumn{2}{|c|}{0,90} & \multicolumn{2}{|c|}{0,85} & \multicolumn{2}{|c|}{0,92} & \multicolumn{2}{|c|}{0,82} & \multicolumn{2}{|c|}{0,95} \\
\hline LKPD & \multicolumn{2}{|c|}{72} & \multicolumn{2}{|c|}{83} & \multicolumn{2}{|c|}{92} & \multicolumn{2}{|c|}{87} & \multicolumn{2}{|c|}{94} \\
\hline
\end{tabular}

Keterangan: LK adalah Lembar Kerja; LKPD adalah Lembar Kerja Peserta Didik; PP adalah Problem Presentation; DP adalah Data Processing; V adalah Verification; C adalah Closure; SM adalah Skor Maksimal; SP adalah Skor Perolehan. 
nilai kepraktisan sebesar 0,86 dari peserta didik dan 0,86 dari guru dengan kategori kepraktisan yang tinggi berdasarkan hasil analisis data praktikalitas dari praktisi.

\section{REFERENSI}

1. Gusty S, Nurmiati N, Muliana M, Sulaiman OK, Ginantra NLWSR, Manuhutu, MA, Sudarso A, Leuwol NV, Apriza A, \& Sahabuddin AA. Belajar Mandiri: Pembelajaran Daring di Tengah Pandemi Covid-19. Yayasan Kita Menulis; 2020,

2. Machin A. Implementasi pendekatan saintifik, penanaman karakter dan konservasi pada pembelajaran materi pertumbuhan. Jurnal Pendidikan IPA Indonesia. 2014;3(1):28-35.

3. Rahmi YL, Novriyanti E, Ardi A, Rifandi R. Developing Guided Inquiry-Based Student Lab Worksheet for Laboratory Knowledge Course. IOP Conference Series Materials Science and Engineering. 2018;335(1).

4. Adhim AY, Jatmiko B. Penerapan Model Pembelajaran Guided Discovery Dengan Kegiatan Laboratorium Untuk Meningkatkan Hasil Belajar Peserta didik Kelas X Sma Pada Materi Suhu Dan Kalor. J Inovasi Pendidikan Fisika. 2015;4(3):77-82.

5. Smitha. Inquiry Training Model and Guided Discovery Learning For Fostering Critical Thinking and Scientific Attitude. Kozhikode: Vilavath Publication; 2012.

6. Illahi M. Pembelajaran Discovery \& Mental Vocational Skill. Yogyakarta: Diva Press; 2012.

7. Mayer RE. Should There Be a Three-Strikes Rule Against Pure Discovery Learning. American Psychologist. 2004; 59(1):14-19.

8. Nahdi DS. Eksperimentasi Model Problem Based Learning Dan Model Guided Discovery Learning Terhadap Kemampuan Pemecahan Masalah Matematis Ditinjau Dari Self Efficacy Siswa. Jurnal Cakrawala Pendas. 2018;4(1).

9. Yerimadesi, Kiram Y, Lufri, Festiyed. Development of guided discovery learning based module on colloidal system topic for senior high school. Journal of Physics: Conference Series. 2018;1116(4).

10. Yerimadesi Y, Bayharti B, Oktavirayanti R. Validitas Dan Praktikalitas Modul Reaksi Redoks dan Sel Elektrokimia Berbasis Guided Discovery Learning untuk SMA. Jurnal Eksakta Pendidikan. 2018;2(1):17.

11. Bayharti B, Azumar OR, Andromeda A, Yerimadesi Y. Effectiveness of redox and electrochemical cell module based guided discovery learning on critical thinking skills and student learning outcomes of high school. Journal of Physics: Conference Series. 2019;1317(1).

12. Majid A, Rochman C. Pendekatan Ilmiah dalam Implementasi Kurikulum 2013. Bandung: Remaja Rosdakarya; 2014.

13. Rahmi YL, Alberida H. Improving Students'
Higher Order Thinking Skills through Portfolio Assessment on Biology Curriculum and Textbook Analysis Course. Bioeducation Journal. 2017;1(1).

14. Aulia A, Andromeda A. Pengembangan E-Modul Berbasis Inkuiri Terbimbing Terintegrasi Multirepresentasi dan Virtual Laboratory pada Materi Larutan Elektrolit dan Nonelektrolit untuk Kelas X SMA/MA. Edukimia. 2019;1(1).

15. Plomp T, Nieveen N. An Introduction to Educational Design Research. In: Proceedings of the seminar conducted at the east China Normal University, Shanghai (PR China). Netherlands Institute for Curriculum Development: SLO; 2007.

16. Retnawati H. Analisis Kuantitatif Instrumen Penelitian. Yogyakarta: Parama Publishing; 2016.

17. Kemendikbud. Panduan praktis Penyusunan E-Modul tahun 2017. Jakarta: Kementerian Pendidikan dan Kebudayaan; 2017.

18. Sukardi HM. Metode Penelitian Tindakan Kelas: Implementasi dan Pengembangannya. Bumi Aksara. Jakarta; 2013.

19. Perdana FA, Sarwanto S, Sukarmin S, Sujadi I. Development of E-Module Combining Science Process Skills and Dynamics Motion Material to Increasing Critical Thinking Skills And Improve Student Learning Motivation Senior High School. International Journal Science and Applied Science: Conference Series. 2017;1(1):45.

20. Rendra GRP, Darmawiguna IGM, Sindu IGP. Pengembangan E-Modul Berbasis Project Based Learning Menggunakan Schoology (Studi Kasus Mata Pelajaran Web Design Kelas XI Multimedia Di SMK TI Bali Global Singaraja). Kumpulan Artikel Mahasiswa Pendidikan Teknik Informatika. 2018;7(2):50,

\section{UCAPAN TERIMA KASIH}

Ucapan terimakasih penulis sampaikan kepada Lembaga Penelitian dan Pengabdian kepada Masyarakat Universitas Negeri Padang yang telah mendanai penelitian ini melalui Dana DIPA UNP Nomor SP DIPA-023.17.2.677514/2021, Tanggal 23 November 2020. 